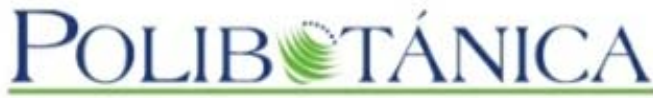

Polibotánica

ISSN electrónico: 2395-9525

polibotanica@gmail.com

Instituto Politécnico Nacional

México

http://www.polibotanica.mx

EFFECT OF TEMPERATURE AND STORAGE TIME ON THE CONCENTRATION OF SOME PHYTOHORMONES AND GERMINATION OF PIQUIN CHILI PEPPER SEEDS Capsicum annuum var. glabriusculum (DUNAL) HEISER \& PICKERSGILL

\title{
EFECTO DE LA TEMPERATURA Y TIEMPO DE ALMACENAMIENTOENLACONCENTRACIÓN DE ALGUNAS FITOHORMONAS Y GERMINACIÓN DE LAS SEMILLAS DEL CHILE PIQUÍN Capsicum annuum var. glabriusculum (DUNAL) HEISER \& PICKERSGILL
}

\begin{abstract}
A.P. López-Valdez, M.A. Alvarado-Vázquez, L. Díaz-Jiménez y A. Rocha-Estrada EFFECT OF TEMPERATURE AND STORAGE TIME ON THE CONCENTRATION OF SOME PHYTOHORMONES AND GERMINATION OF PIQUIN CHILI PEPPER SEEDS Capsicum annuum var. glabriusculum (DUNAL) HEISER \& PICKERSGILL

EFECTO DE LA TEMPERATURA Y TIEMPO DE ALMACENAMIENTO EN LA CONCENTRACIÓN DE ALGUNAS FITOHORMONAS Y GERMINACIÓN DE LAS SEMILLAS DEL CHILE PIQUÍN Capsicum annuum var. glabriusculum (DUNAL) HEISER \& PICKERSGILL
\end{abstract}

\section{POLIBETÁNICA}

Instituto Politécnico Nacional
Núm. 50: 83-95 México. Agosto 2020

DOI: $10.18387 /$ polibotanica.50.6

(c) (†) Este es un artículo de acceso abierto bajo la licencia Creative Commons 4.0 Atribución-No Comercial (CC BY-NC 4.0 Internacional). 
EFFECT OF TEMPERATURE AND STORAGE TIME ON THE CONCENTRATION OF SOME PHYTOHORMONES AND GERMINATION OF PIQUIN CHILI PEPPER SEEDS Capsicum annuum var. glabriusculum (DUNAL) HEISER \& PICKERSGILL

\section{EFECTO DE LA TEMPERATURA Y TIEMPO DE ALMACENAMIENTO EN LA CONCENTRACIÓN DE ALGUNAS FITOHORMONAS Y GERMINACIÓN DE LAS SEMILLAS DEL CHILE PIQUÍN Capsicum annuum var. glabriusculum (DUNAL) HEISER \& PICKERSGILL}

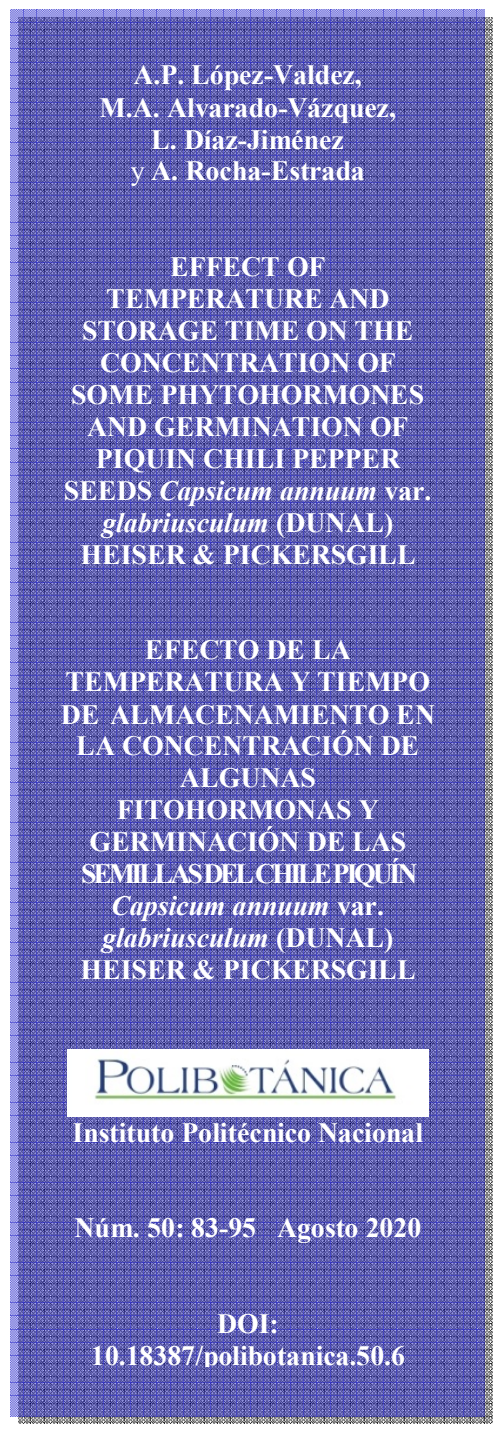

\author{
A.P. López-Valdez \\ M.A. Alvarado-Vázquez / marco.alvaradovz@uanl.edu.mx \\ Universidad Autónoma de Nuevo León, Facultad de Ciencias Biológicas. \\ Ave. Pedro de Alba s.n., Ciudad Universitaria, \\ San Nicolás de los Garza, Nuevo León, México. CP 66455. \\ L. Díaz-Jiménez \\ CINVESTAV unidad Saltillo. Laboratorio de Revaloración de Residuos, \\ Sustentabilidad de los Recursos Naturales y Energía. \\ Ramos Arizpe, Coahuila, México.
}

\author{
A. Rocha-Estrada \\ Universidad Autónoma de Nuevo León, Facultad de Ciencias Biológicas. \\ Ave. Pedro de Alba s.n., Ciudad Universitaria, \\ San Nicolás de los Garza, Nuevo León, México. CP 66455.
}

ABSTRACT: The genus Capsicum is an economically important plant around the world. In Mexico, chili cropping is a profitable agricultural business due to its demand in the national and international market. A species of interest is the piquín chili pepper, Capsicum annuum var. glabriusculum (Dunal) Heiser \& Pickersgill, whose exploitation is limited only to wild populations. There have been many unsuccessful attempts to cultivate it intensively because of its low germination percentage, since the seed shows non-deep physiological dormancy, a frequent feature in undomesticated wild species. In this study, the effect of temperature and times of storage of piquín chili pepper seed on the concentration of tryptophan (auxin precursor amino acid), cytokinins (kinetin) and gibberellins $\left(\mathrm{GA}_{3}\right)$ and their germinative capacity were analyzed. For this, the germinative capacity of pepper seeds stored at two temperatures $\left(4\right.$ and $\left.24{ }^{\circ} \mathrm{C}\right)$ and five times $(0,3,6,9$ and 12 months) was evaluated. Also, quantification of the phytohormones auxins, cytokinins and gibberellins was performed using high performance liquid chromatography (HPLC). The results show that the content of the three phytohormones had increased through time according to the time of storage. The highest germination percentage was at 9 months of storage and this was the highest content of the three phytohormones; however, at 12 months of storage, germination started diminishing as well as the phytohormone content, indicating that the seed quality and viability was starting to decrease.

Key words: seeds, auxins, cytokinins, gibberellins, piquin chili pepper, germination, phytohormones

RESUMEN: El género Capsicum es una hortaliza de importancia económica a nivel mundial. En México es una importante actividad económica en el sector agrícola, por ello la importancia del cultivo de variedades que permitan abrir nuevas áreas de oportunidad comercial tanto a nivel nacional como internacional. Una de estas 
variedades es el chile piquín Capsicum annuum var. glabriusculum (Dunal) Heiser \& Pickersgill, cuyo aprovechamiento se reduce únicamente a poblaciones silvestres, ya que se han hecho varios intentos de cultivarla de manera intensiva teniendo como resultado bajos porcentajes de germinación, debido a que la semilla presenta latencia fisiológica no profunda, rasgo característico de especies que aún no han sido domesticadas. En este estudio se propuso conocer el efecto de la temperatura y el tiempo de almacenamiento, sobre el contenido de triptófano (aminoácido precursor de auxinas), citocininas (kinetina) y giberelinas $\left(\mathrm{GA}_{3}\right)$ presentes en la semilla y su relación en el proceso de germinación. Para evaluar la capacidad de germinación de las semillas de chile piquín, estas se almacenaron a dos temperaturas $\left(4^{\circ} \mathrm{C}\right.$ y 24 $\left.{ }^{\circ} \mathrm{C}\right)$ y cinco tiempos de almacenamiento $(0,3,6,9$ y 12 meses). Además, se cuantificó el contenido de fitohormonas, auxinas, citicininas y giberelinas utilizándose la técnica de Cromatografía Líquida de Alta Resolución (HPLC). Los resultados muestran que el contenido de las tres fitohormonas se incrementó con respecto al tiempo de almacenamiento. El más alto porcentaje de germinación y concentración de fitohormonas se presentó a los 9 meses de almacenamiento; mientras que, a los 12 meses, la germinación empieza a disminuir, así como el contenido de fitohormonas, indicando que la calidad y viabilidad de la semilla ha empezado a decrecer.

Palabras clave: semillas, auxinas, citocininas, giberelinas, chile piquín, germinación, fitohormonas.

\section{INTRODUCTION}

Economically, Capsicum annuum L. is one of the most important crops in the world due to its great demand in gastronomy, medicine and cosmetics (Quintero et al., 2018; Yamamoto \& Nawata, 2005). It is also an important source of vitamin C, protein, fiber and minerals. Chile peppers comprise a large variety of pungent and mild chilis such as ancho, cayenne, habanero, jalapeno, poblano and serrano. There are five domesticated species of Capsicum which are $C$. annuum, C. frutescens, C. chinense, C. pubescens, and C. baccatum (Hulse-Kemp et al., 2016); the wild ancestor of Capsicum annuum is the piquín chili pepper, Capsicum annuum var. glabriusculum (Dunal) Heiser \& Pickersgill. This is a variety that spreads from the southern United States to northern Brazil. In Mexico, the harvest of piquín chili pepper is considered an attractive activity due to the high prices that this product can reach in the local market. This species belongs to the Solanaceae family, and it has a low germination rate since the seed has non-deep physiological dormancy, i.e., dormancy in the embryo stage (Alcalá Rico et al., 2019; Baskin \& Baskin, 2004; Cano-Vázquez et al., 2015). This natural phenomenon has been related to phytochromes, temperature or phytohormones (Baskin \& Baskin, 2014). Capsicum annuum var. glabriusculum has orthodox seeds with a development that is completed when the seed matures, dries, and stores some compounds (starch, proteins and lipids). When seed water content decreases, then the seed becomes tolerant to desiccation with dormancy finally appearing (Finkelstein, Reeves, Ariizumi, \& Steber, 2008). Linkies, Graber, Knight, \& Leubner-Metzger (2010) point out that these orthodox features let seeds survive for long periods and under harsh environmental conditions, enabling the timing of seed germination to weather conditions that are favorable for germination and further seedling development. Phytohormones are important to start, keep, and end dormancy, since they are involved in the germination, growth and development processes during a plant life cycle. Yamauchi et al. (2004) found in tomato and Arabidopsis thaliana that physiological, biochemical and genetic activities are related to gibberellic acid (GA), which weakens the layers that surround the embryo during germination such as aleurone and seed coat. For radicle emergence, it is necessary that the seed be imbibed in water so the micropylar endosperm can be weakened by cell wall hydrolysis along with enzymes that are activated via GA that induce cell wall hydrolases (Leubner-Metzger, 2003). Auxins can interfere in seed germination when abscisic acid (ABA) appears in the seed (Brady, Sarkar, Bonetta, \& McCourt, 2003). Indoleacetic acid (IAA) is the most studied auxin and has tryptophan as a precursor, IAA influences seed germination by regulating the activity of enzymes such as glyoxalase I (which is in pea seeds), 
which results in higher rates of cell growth and development (Hentrich et al., 2013). Auxins also control plants, embryo and seed radicle growth and development during and after germination, leaf and root growth (Popko, Hansch, Mendel, Polle, \& Telchmann, 2010). Other types of phytohormones that are involved during germination are cytokinins, which are present in all stages of germination (Chiwocha et al., 2005). Linkies \& Leubner-Metzger (2011) mentioned that GA is involved in processes such as shoot growth, flower development, dormancy release and seed germination. These plant hormones can be found in roots, young leaves, developing fruits and seeds (Wang \& Irving, 2011). In the present study, the content of plant hormones such as cytokinins and gibberellins, and an auxin precursor (tryptophan) were quantified during five times of storage $(0,3,6,9$ and 12 months) and two storage temperatures ( 4 and $24{ }^{\circ} \mathrm{C}$ ) of piquín chili pepper seeds in order to know their relationship with seed germination.

\section{MATERIAL AND METHODS}

\section{Chemicals and reagents}

All standards used for quantification (gibberellic acid 3, kinetin and tryptophan) and solvents were purchased from Sigma-Aldrich (Saint Louis, MO, USA). Biogib (commercial gibberellic acid $\mathrm{GA}_{3}$ ) and commercially sterile soil were purchased from a fertilizer and gardening store.

\section{Plant growth and harvest}

Wild piquín chili pepper fruits were supplied from the School of Forestry of the Universidad Autonóma of Nuevo León. Red, mature, good appeal and free of pathogen fruits were selected; after that, seeds were extracted. Yellow, complete and free spotted seeds were chosen to grow. A total of 500 seeds were imbibed in a $5000 \mathrm{ppm} \mathrm{GA}$ solution for $24 \mathrm{~h}$ to promote germination. Later, the seeds were sown in sterile soil; 350 seeds germinated and the seedlings were placed in a plant nursery. When the plants grew, fruits were harvested (red and ripe fruits were selected) from October to December, then dehydrated at room temperature for a month and subsequently divided in two groups, group A was stored at $4{ }^{\circ} \mathrm{C}$ and group B at $24{ }^{\circ} \mathrm{C}$. The storage time was 12 months, but samples were taken at $0,3,6,9$ and 12 months for phytohormone analysis and germination trials.

\section{Phytohormone profiling}

Sample Extraction

A sample of $3.5 \mathrm{~g}$ of seeds from each group were lyophilized for $36 \mathrm{~h}$, and then seeds were frozen at $-72{ }^{\circ} \mathrm{C}$ for $72 \mathrm{~h}$. After three days, seeds from group A $\left(4{ }^{\circ} \mathrm{C}\right)$ and $\mathrm{B}\left(24{ }^{\circ} \mathrm{C}\right)$ were ground $(50 \mathrm{mg})$ to a powder. Five repetitions of each treatment were done and transferred into an Eppendorf tube. Phytohormone extraction was done by adding $1.5 \mathrm{~mL} 80 \% \mathrm{MeOH}$. Then, samples were sonicated for $10 \mathrm{~min}$ and kept in refrigeration for $72 \mathrm{~h}$. Afterwards, samples were homogenized under a vortex for $5 \mathrm{~min}$. Then, they were centrifuged for $15 \mathrm{~min}$ at $1000 \mathrm{rpm}$ $24{ }^{\circ} \mathrm{C}$. The supernatant was transferred to a $2 \mathrm{~mL}$ Eppendorf tube. Phytohormones were separated on a $\mathrm{C} 18$ reversed phase column with two rinses; the first rinsed consisted of $20 \%$ methanol $+0.1 \%$ formic acid, the second rinsed consisted of $80 \%$ methanol. The eluent was transferred to a $2 \mathrm{~mL}$ Eppendorf tube. An aliquot of $1 \mathrm{~mL}$ of each seed group phytohormone extract was transferred to an amber vial to be analyzed by HPLC (Agilent Technologies 1200). This procedure was repeated at $3,6,9$ and 12 months of seeds storage at $4{ }^{\circ} \mathrm{C}$ and $24^{\circ} \mathrm{C}$.

\section{Preparation of standard solutions}

For calibration, phytohormone standards were mixed and serially diluted with acetonitrile $(0.5 \%) ; 10,20,40,60,100 \mathrm{ppm}$ for gibberellic acid, tryptophan (as an indoleacetic acid precursor) and kinetin. The calibration samples were transferred to amber vials with glass inserts to be analyzed by HPLC. 


\section{Chromatographic conditions}

Phytohormones were separated on a Phenomenex Kinetex C18 reversed phase column, with an isocratic elution, using methanol/acetonitrile $0.5 \%(5: 5, \mathrm{v} / \mathrm{v})$ as an eluent. Flow rate $0.3 \mathrm{~mL}$ $\min ^{-1}$, pressure $68 \mathrm{bar}$, and column wash for $2 \mathrm{~min}$ were used. Detection was done through fluorescence, $280 \mathrm{~nm}$ exciting $\lambda$, emission $360 \mathrm{~nm}$, low sensibility. Phytohormone quantification was based on the sample peak area measurement with the calibration curve.

\section{Calibration curve and linearity}

A five-point calibration curve was prepared with GA, kinetin and tryptophan (10, 20, 4060 and $100 \mathrm{ppm}$ ). Correlation coefficient $\left(R^{2}\right)$ and residual plots were used to evaluate the linearity of the calibration curve for each phytohormone and metabolite. To do so, the residual of each point of the calibration curve (difference between the calculated and theoretic values) was plotted against the concentration level. In order to get an adequate regression model, the residuals are normally distributed along the X-axis (Almeida, Castel-Franco, \& Falcao, 2002). A linear regression was used in the calibration curve for all phytohormones and metabolite.

\section{Seed germination}

To evaluate germination, stored seeds at $4{ }^{\circ} \mathrm{C}$ and $24{ }^{\circ} \mathrm{C}$ were taken every three months; 100 seeds of each group were used, with 5 repetitions of 20 seeds each. Seeds were imbibed in water for 24 hours. They were sown in a seedbed with commercial sterile soil and placed in a climate chamber $\left(25^{\circ} \mathrm{C}\right)$, and were watered and registered every day for a month. Germination was considered positive once the radicle emerged.

\section{Statistical analysis}

In this study, a factorial design was used; data were analyzed using multifactorial variance analysis (ANOVA) with IBM SPSS Statistics 20.0. Mean separation was performed by Fisher's least significant difference (LSD) test and the Pearson correlation test was used to evaluate the relationship between variables. Significant differences were determined at $\mathrm{p} \leq 0.05$ probability level.

\section{RESULTS}

\section{Phytohormone quantification Tryptophan}

The concentration of the amino acid tryptophan, a precursor of auxins found in piquín chili pepper seeds, had a general mean value according to the times of storage of the seeds of 17.89 ppm with the lowest value at 0 months $(10.01 \mathrm{ppm})$, increasing at 3 and 6 months (10.83 and $14.18 \mathrm{ppm}$, respectively) and reaching its maximum value at 9 months and at a temperature of $24{ }^{\circ} \mathrm{C}(34.56 \mathrm{ppm})$, decreasing later at 12 months (19.51 ppm).

The tryptophan values recorded showed significant differences (ANOVA) both in months of storage $(p=0.000)$, storage temperatures $(p=0.000)$, and the interaction of both factors $(p=$ $0.000)$. At all times of storage evaluated, the tryptophan concentration was greater in seeds stored at $24{ }^{\circ} \mathrm{C}$ (fig. 1, table 1). At this temperature, differences in the concentration of this amino acid were not observed at 0 and 3 months $(\mathrm{p} \geq 0.05)$, while at $4{ }^{\circ} \mathrm{C}$ the concentration was only different at 6 and 9 months of storage $(\mathrm{p} \leq 0.05)$.

\section{Gibberellins (GA3)}

The mean concentration of $\mathrm{GA}_{3}$ at the five storage times was $38.04 \mathrm{ppm}$, although this value was less in seeds stored at $4{ }^{\circ} \mathrm{C}$ where the mean for the five storage times was $3.31 \mathrm{ppm}$ and greater for seeds stored at $24{ }^{\circ} \mathrm{C}$ where the concentration of $\mathrm{GA}_{3}$ reached a mean of $41.82 \mathrm{ppm}$. In seeds stored at $4{ }^{\circ} \mathrm{C}$, the concentration of $\mathrm{GA}_{3}$ is less than at $24{ }^{\circ} \mathrm{C}$ at all storage times but the pattern is similar with a maximum value of $46.95 \mathrm{ppm}$ at 9 months with a later decrease at 12 months at $33.31 \mathrm{ppm}$ (fig. 1, table 1). 
The ANOVA showed significant differences in $\mathrm{GA}_{3}$ concentrations both in months of storage $(p=0.000)$, storage temperatures $(p=0.000)$, and the interaction of both factors $(p=0.000)$.

\section{Kinetin}

Kinetin is a hormone of the cytokinins group. The results obtained showed that the concentration of this hormone in piquín chili pepper seeds had a mean during the 12 months of storage of $2.64 \mathrm{ppm}$, with this being greater in seeds stored at $24{ }^{\circ} \mathrm{C}$ where it reached $4.34 \mathrm{ppm}$, while at $4{ }^{\circ} \mathrm{C}$, the mean was only $0.51 \mathrm{ppm}$. At both temperatures, the concentration started at $0.00 \mathrm{ppm}$ at 0 months and increased with storage time reaching a maximum mean concentration at 9 months of $1.25 \mathrm{ppm}$ and $12.11 \mathrm{ppm}$ for seeds stored at 4 and $24{ }^{\circ} \mathrm{C}$, respectively. After this, the concentration decreased in both temperatures (fig. 1, table 1).

The differences observed in the kinetin concentration are significant (ANOVA, $p \leq 0.05$ ) for the storage times, the temperatures, and the interaction of both factors.

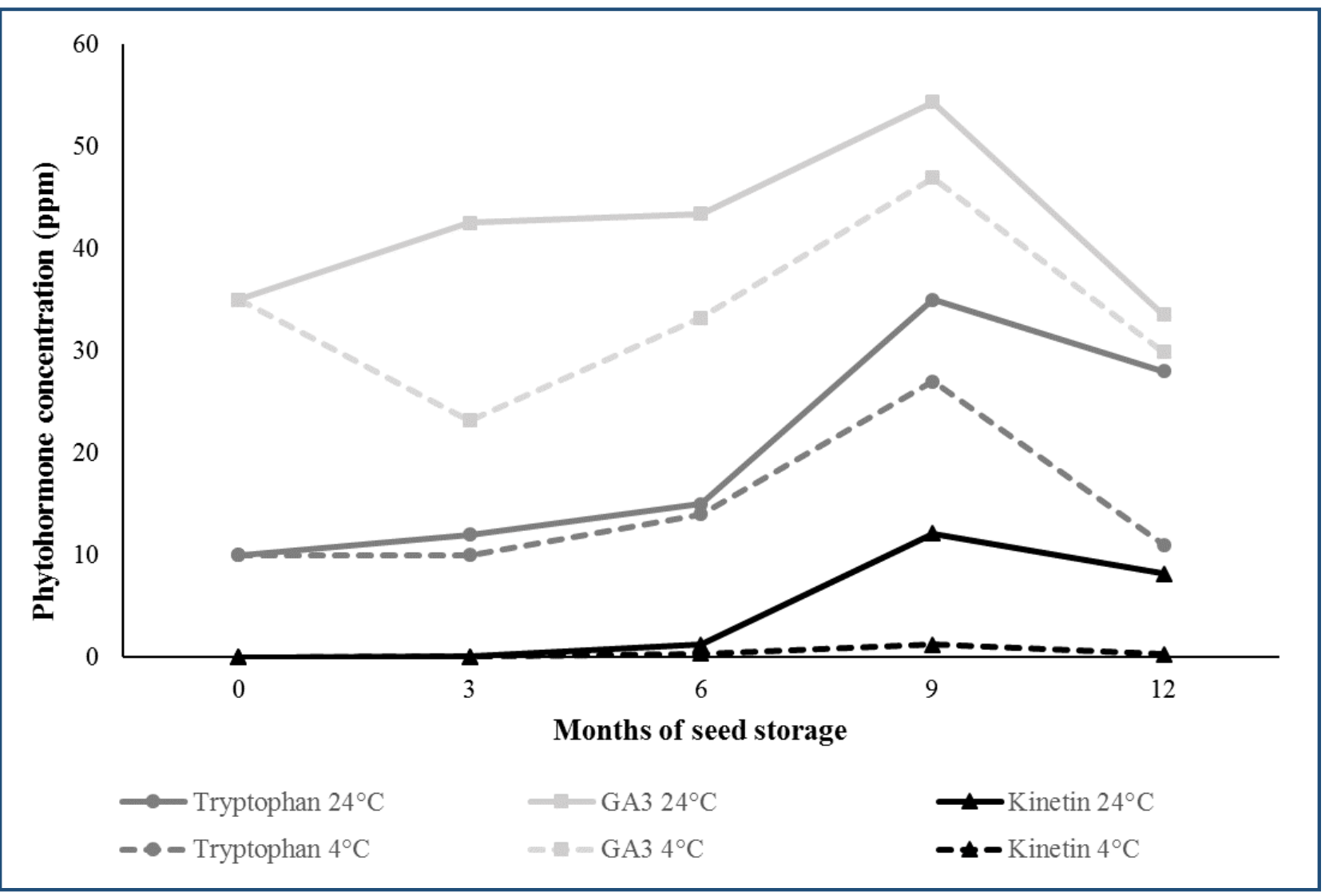

Fig. 1. Mean concentration of tryptophan, kinetin and gibberellic acid $\left(\mathrm{GA}_{3}\right)$ in piquín chili pepper seeds, Capsicum annuиm var. glabriusculum (Dunal) Heiser \& Pickersgill, stored at two temperatures (4 and $24{ }^{\circ} \mathrm{C}$ ) at five different storage times. 
Table 1. Mean concentration ( \pm standard deviation) and $\operatorname{LSD}_{0.05}$ of phytohormones in piquín chili pepper seeds, Capsicum annuum var. glabriusculum (Dunal) Heiser \& Pickersgill, stored at two temperatures $\left(4\right.$ and $\left.24{ }^{\circ} \mathrm{C}\right)$ at five different storage times.

\begin{tabular}{ccccccc}
\hline Phytohormone & $\begin{array}{c}\text { Storage } \\
\text { temperature }\end{array}$ & $\mathbf{0}$ & $\mathbf{3}$ & $\mathbf{6}$ & $\mathbf{9}$ & $\mathbf{1 2}$ \\
\hline \multirow{2}{*}{ Tryptophan } & $\mathbf{4}^{\circ} \mathbf{C}$ & $10.01 \pm 0.06^{\mathrm{a}}$ & $10.19 \pm 0.44^{\mathrm{a}}$ & $13.79 \pm 0.18^{\mathrm{b}}$ & $27.37 \pm 2.65^{\mathrm{c}}$ & $10.83 \pm 0.15^{\mathrm{a}}$ \\
& $\mathbf{2 4}{ }^{\circ} \mathbf{C}$ & $10.01 \pm 0.06^{\mathrm{a}}$ & $11.47 \pm 0.32^{\mathrm{a}}$ & $14.56 \pm 0.33^{\mathrm{b}}$ & $34.56 \pm 3.69^{\mathrm{d}}$ & $28.18 \pm 1.84^{\mathrm{c}}$ \\
& & & & & & \\
Gibberellins & $\mathbf{4}^{\circ} \mathbf{C}$ & $35.30 \pm 2.12^{\mathrm{c}}$ & $23.17 \pm 1.22^{\mathrm{a}}$ & $33.22 \pm 3.08^{\mathrm{c}}$ & $46.95 \pm 1.4^{\mathrm{d}}$ & $29.89 \pm 2.21^{\mathrm{b}}$ \\
& $\mathbf{2 4}{ }^{\circ} \mathbf{C}$ & $35.30 \pm 2.12^{\mathrm{a}}$ & $42.54 \pm 2.65^{\mathrm{b}}$ & $43.40 \pm 2.02^{\mathrm{b}}$ & $54.35 \pm 1.96^{\mathrm{c}}$ & $33.52 \pm 0.97^{\mathrm{a}}$ \\
& & & & & & \\
Kinetin & $\mathbf{4}^{\circ} \mathbf{C}$ & $00.00 \pm 0.00^{\mathrm{a}}$ & $00.07 \pm 0.06^{\mathrm{ab}}$ & $00.39 \pm 0.15^{\mathrm{b}}$ & $01.25 \pm 0.50^{\mathrm{c}}$ & $00.34 \pm 0.21^{\mathrm{ab}}$ \\
& & & & & & \\
& $\mathbf{2 4}{ }^{\circ} \mathbf{C}$ & $00.00 \pm 0.00^{\mathrm{a}}$ & $00.09 \pm 0.12^{\mathrm{a}}$ & $01.25 \pm 0.50^{\mathrm{a}}$ & $12.11 \pm 1.81^{\mathrm{c}}$ & $08.26 \pm 1.56^{\mathrm{b}}$
\end{tabular}

Different letters in the same row indicate significant differences between storage times according to Fisher's least significant difference (LSD) test $(\mathrm{P} \leq 0.05)$.

\section{Seed germination. The effect of temperature and storage time}

Storage times $\left(0,3,6,9\right.$ and 12 months), storage temperatures $\left(4\right.$ and $\left.24{ }^{\circ} \mathrm{C}\right)$ and interaction of both factors showed a significant effect on seed germination (ANOVA, $\mathrm{p} \leq 0.05$ ). Seeds with 0 months of storage had a mean germination of $52.0 \%$, decreasing later at 3 and 6 months of storage, then increasing at 9 months, and decreasing again at 12 months (table 2). This occurred at both temperatures; however, at all storage times, the germination percentage was greater in seeds stored at $24{ }^{\circ} \mathrm{C}(\mathrm{p} \leq 0.05)$.

These results show that in seeds stored at 4 and $24{ }^{\circ} \mathrm{C}$, the greater germination percentage is reached at 9 months with a value of $36 \%$ and $54 \%$, respectively; while the lowest germination percentage occurred at 12 months in both seed groups.

Table 2. Average values ( \pm standard deviation) and $\mathrm{LSD}_{0.05}$ of germination percentage of piquín chili pepper seeds, Capsicum annuum var. glabriusculum (Dunal) Heiser \& Pickersgill, stored at two temperatures $\left(4\right.$ and $\left.24^{\circ} \mathrm{C}\right)$ and five different storage times.

\begin{tabular}{lccccc}
\hline $\begin{array}{c}\text { Storage } \\
\text { temperature }\end{array}$ & $\mathbf{0}$ & $\mathbf{3}$ & Months of storage & $\mathbf{6}$ & $\mathbf{1 2}$ \\
\hline $\mathbf{4}^{\circ} \mathbf{C}$ & $52.00 \pm 7.75^{\mathrm{d}}$ & $14.00 \pm 5.07^{\mathrm{b}}$ & $14.00 \pm 5.07^{\mathrm{b}}$ & $36.00 \pm 10.56^{\mathrm{c}}$ & $4.00 \pm 5.07^{\mathrm{a}}$ \\
$\mathbf{2 4}^{\circ} \mathbf{C}$ & $52.00 \pm 7.75^{\mathrm{c}}$ & $42.00 \pm 28.83^{\mathrm{bc}}$ & $36.00 \pm 14.04^{\mathrm{ab}}$ & $54.00 \pm 19.20^{\mathrm{c}}$ & $24.00 \pm 10.56^{\mathrm{a}}$ \\
\hline
\end{tabular}

Different letters in the same row indicate significant differences between storage times according to Fisher's least significant difference (LSD) test $(\mathrm{p} \leq 0.05)$. 
Correlation between temperature and storage time, hormone concentration and germination response

In general, it was found that seed time and storage temperature are clearly related with hormone concentration and germination capacity of piquín chili pepper seeds (table 3 ). In this regard, it was found that the kinetin concentration in seeds had a positive relation with storage time $(\mathrm{r}=$ $0.526)$ and storage temperature $(\mathrm{r}=0.481)$. On the other hand, gibberellins also had a positive relation with temperature $(\mathrm{r}=0.461)$ but not with storage time $(\mathrm{r}=0.170)$; tryptophan showed a strong relation with storage time $(r=0.623)$ and storage temperature $(r=0.299)$.

With regard to the germination response, a positive relation with temperature $(\mathrm{r}=0.410)$ and an inversely proportional relation with storage time $(r=-0.389)$ were seen. When comparing the germination percentage with the concentration of hormones, a positive relation was found between the germination percentage and the concentration of gibberellins $(r=0.541)$, while the concentration of kinetin and tryptophan did not show a significant relationship with germination.

Table 3. Pearson correlation values (r) obtained between phytohormones concentrations, germination, storage temperature and storage time in piquín chili pepper seeds, Capsicum annuum var. glabriusculum (Dunal) Heiser \& Pickersgill.

\begin{tabular}{|c|c|c|c|c|c|c|}
\hline & Kinetin & Gibberellins & Tryptophan & Germination & $\begin{array}{c}\text { Storage } \\
\text { time }\end{array}$ & $\begin{array}{c}\text { Storage } \\
\text { temperature }\end{array}$ \\
\hline \multicolumn{7}{|l|}{ Kinetin } \\
\hline Gibberellins & $0.502 * *$ & & & & & \\
\hline Tryptophan & $0.850 * *$ & $0.645 * *$ & & & & \\
\hline Germination & $0.214^{\mathrm{NS}}$ & $0.541 * *$ & $0.216^{\mathrm{NS}}$ & & & \\
\hline Storage time & $0.526^{* *}$ & $0.170^{\mathrm{NS}}$ & $0.623 * *$ & $-0.389 * *$ & & \\
\hline $\begin{array}{c}\text { Storage } \\
\text { temperature }\end{array}$ & $0.481 * *$ & $0.461 * *$ & $0.299 *$ & $0.410 * *$ & $0.000^{\mathrm{NS}}$ & \\
\hline
\end{tabular}

\section{DISCUSSION}

In this study, the effect of temperature and seed storage on germination and phytohormone content was evaluated at different times of storage $(0,3,6,9$ and 12 months). The results observed on germination related with seed maturity coincided with De Souza, Fernandes dos Santos Dias, dos Santos Dias, \& Finger (2011) who found that production of high quality seeds in sweet pepper (Capsicum annuum L.) depends on the appropriate time of harvest; seed crops should be harvested when seed quality is maximal at the end of maturation when the maximum dry matter content of the seeds has been achieved and should be harvested when fruits are completely red outside. In this study, in order to get a higher germination percentage, it was considered of importance to collect fruits that were ripened, red and healthy. Also, the seed must have had a postharvest dehydration time and low moisture content. In an assay by Demir, Mavi, \& Oztokat (2004) in watermelon seeds, it was observed that seeds attain maximum quality at the end of the seed-filling period, and thereafter viability and vigor decline. Therefore, according to economical and agronomical interests to invest on this species, the results observed in this study, suggest that 9 months is the best time of storage to sow the seed and get the highest percentage value.

From an ecological point of view, plants have to adapt the timing of germination to the surrounding environmental conditions to prevent germination during seasons when the conditions for subsequent seedling establishment and plant growth would be unfavorable 
(Linkies \& Leubner-Metzger, 2012). Hernández-Verdugo et al. (2012) studied piquín chili pepper germination and noticed that the more similar biotic and abiotic factors are to the seeds origin, the greater the germination. That is why in this study the major germination percentage was observed at $24^{\circ} \mathrm{C}$, since the annual temperature from the place where seeds were collected oscillates from $22{ }^{\circ} \mathrm{C}$ to $23^{\circ} \mathrm{C}$. Also, different germination percentages in this species is related to genetic factors, since it has not been manipulated yet and is about a wild type seed. According to Holdsworth, Bentsink, \& Soppe (2008) dormancy is a very complex trait determined by genetic factors and environmental cues. Differences in the germination of different seed cultivars are related to their gene complement (Miransari \& Smith, 2014). Due to this characteristic of species that have not been domesticated, piquín chili pepper seeds show, in this study, a different germination pattern since it is a plant that reproduces sexually and the genes have not been manipulated so as to have a plant production with a more homogeneous germination rate.

There is a direct relationship between the phytohormone concentration and seed physiology and its relationship with seed maturity and seed dormancy. Phytohormones need to be present in seeds in a proper concentration so that they can mature, germinate and reach higher germination percentage. Also, seed viability depends on phytohormone concentration, since with time, concentrations diminish, decreasing seed quality. Germination is a process that is regulated by the interaction of several phytohormones, Bentsink \& Koorneef (2008) confirmed that natural and synthetic gibberellins enhance germination. On the other hand, the phytohormone, indoleacetic acid (IAA), promotes cell division, expansion and differentiation, growth and development (Koprivova \& Kopriva, 2016). As to seed maturity, Leszek (2003) mentioned that when seeds reach maturity, the amount of nutrients and water content is high, therefore, metabolic activities finally begin at the last moment of seed development; the seed loses water content and enters into dormancy. Once dormancy ends, the seed must be kept in a humid environment; at this time, seeds start to absorb water. Gibberellins stimulate the synthesis and production of hydrolases, especially -amylase, resulting in seed germination (Yamaguchi, 2008). During development of different plant parts, auxin controls the embryo, leaf and root (Popko et al., 2010). Auxin is present in the seed radicle tip during and after seed germination. The accumulated IAA in the seed cotyledon is the major source of IAA for the seedlings (Hentrich et al., 2013). For this reason, in this study, the highest germination rate was at 9 months of seed storage. Seeds reached their maturation point at that time, when the seeds showed the highest content of tryptophan, gibberellins and kinetin, since these phytohormones are involved in germination, with gibberellins being the ones needed for endosperm weakening, and the interaction of GA with tryptophan influences germination. Meanwhile cytokinins regulate plant activities such as seed germination. They are present in all stages of germination acting on meristematic cell development in roots and shoots. It is a fact that these plant hormones start synthetizing during seed development, reaching during fresh seeds ( 0 months of storage), a higher concentration of gibberellins so they can germinate, but it was at 9 months of seed storage that seeds reached the proper concentration so as to reach a higher germination percentage. However, the phytohormone content diminished at 12 months of seed storage and that effect was observed on germination percentage since it started lower at that time. It might be possible that the phytohormone content started diminishing from 10 to 11 months of storage, therefore, at that time, seeds started losing quality and viability, having as a result less germination. De Souza et al. (2011) confirm that maximum seed quality in sweet pepper was obtained approximately 75 days after anthesis (DAA) when the fruits had a red color outside coinciding with mass maturity, represented by maximum dry matter content; however, seeds attain maximum quality at the end of the seed-filling period and viability and vigor start declining.

When the seed starts its development, auxin, gibberellin and cytokinin content are high; specifically, cytokinins are more abundant when the endosperm is liquid. This hormone is important because it is involved in cell division while the embryo is provided with gibberellins (Miransari \& Smith, 2011). During half seed development, auxins, gibberellins and cytokinins 
are abundant; however, ABA content starts increasing and nutrients are stored. However, at the final stage, all hormone content gradually diminishes, even ABA. It is possible that this explains the low concentration observed in the phytohormones under study in the newly harvested seeds ( 0 months of storage). Leszek (2003) indicated that during endodormancy there are many hormonal changes and they are complex and dynamic, and these changes are present at certain stages during seed development. However, endodormancy may vary according to the species as well as the hormone concentration; for example, when adding exogen gibberellins to plants, the hormone reduces dormancy but in Dioscorea cayenensis, $\mathrm{GA}_{3}$ increases the time of dormancy. Drew, Pammenter, \& Berjak (2000) observed on Trichilia degeana that seed loses viability after 8 days of storage. This seed quality depends on the species. In this study germination started to diminish at 12 months of storage.

Phytohormones have an important role in plant growth and development and they can act in response to environmental factors (Denancé, Sánchez, Goffner, \& Molina, 2013). Since phytohormones occur in plants at low concentrations and are chemically different, it is hard to quantify them. Also, phytohormone content depends on the tissue being researched (Barkawi, Tam, Tillman, Normanly, \& Cohen, 2010). In this study, a single method was used to identify and quantify kinetin, tryptophan and gibberellins in order to know how their concentration physiologically influences seed maturity and germination. It is a validated method that quickly identifies and quantifies several phytohormones. During the analyses of phytohormones, there are many metabolites whose chemical structure might be similar to the phytohormone of interest (Ma et al., 2008). Therefore, the amount of phytohormone identified may depend on the tissue studied, the technique used, the equipment sensitivity, solvents and handling. In this study, it was registered that at 9 months of storage, independently of storage temperature, the piquín chili pepper seeds showed higher phytohormone concentration for the two phytohormones and the precursor studied, which could be detected by HPLC analysis. Also, at 9 months of seed storage, the highest germination percentage was reported. It was also reported that at 12 months of storage phytohormone content started diminishing and it had a physiological effect on germination since at 12 months of seed storage germination also diminished. In comparison with the results achieved by Tommasi, Paciolla, de Pinto, \& Gara (2006) who evaluated the effect of temperature on Ginkgo biloba seeds that were stored at $4{ }^{\circ} \mathrm{C}$ and $25{ }^{\circ} \mathrm{C}$, at 6 months of storage, all seeds died when stored at $25{ }^{\circ} \mathrm{C}$. However, cold temperature helped keep seed tissue viability for a year, but they were not able to germinate at 6 months either. When they analyzed ascorbate and glutathione concentration in embryo and endosperm they found no change in the first 9 months of storage at $4{ }^{\circ} \mathrm{C}$. At $25{ }^{\circ} \mathrm{C}$ ascorbate content diminished in the embryo, whereas in the endosperm it remained stable. In a study done by Suttle \& Banowetz (2000) it was found that depending on the time and storage temperature, the amount of cis-zeatin and cis-zeatin riboside oscillates from 24 and $102 \mathrm{pmol}(\mathrm{g}$ fresh weight) in potato tuber. Tarkowski, Ge, Yong, \& Ngin (2009) mentioned that cytokinins are found in low quantities, below $30 \mathrm{pmol} / \mathrm{g}$ of fresh weight. Munné-Bosch, Onate, Oliveira, \& Garcia (2011) found changes in phytohormones associated with a loss of seed germination capacity in buried Vellozia alata seeds. Loss of germination percentage was linked with a very significant decline in GA, ABA and cytokinins; IAA remained constant during the first three months of study. After 6 months of burial, phytohormone concentrations remained unaltered, metabolic activity in seeds decreased very significantly, and seed germination capacity remained constant at least one year. In this study, it was observed that at 12 months of storage, seed capacity and phytohormone content started to decline. This is related to seed imbibition which leads to changes in metabolism, comprising that of phytohormones (Preston et al., 2009).

\section{CONCLUSIONS}

There are differences in the kinetin, tryptophan and gibberellic acid concentrations in piquín chili pepper seeds with different storage times and temperatures. The concentration of these hormones increases with storage time and reaches a maximum concentration at 9 months. Seeds 
stored at $24{ }^{\circ} \mathrm{C}$ have greater hormone concentration values than those stored at $4{ }^{\circ} \mathrm{C}$. The germination percentage of piquín chili pepper seeds is affected by storage temperature and time, reaching a greater germination at 9 months and at a temperature of $24^{\circ} \mathrm{C}$. In piquín chili pepper seeds, the hormone concentration, storage temperature and storage time show a relationship that seems to affect its germination capacity.

\section{ACKNOWLEDGEMENTS}

We acknowledge Facultad de Ciencias Biológicas de la Universidad Autónoma de Nuevo Leon and CONACYT from Mexico the funding for the project.

\section{LITERATURE CITED}

Alcalá Rico, J. S. G. J., López Benítez, A., Vázquez Badillo, M. E., Sánchez Aspeytia, D., Rodríguez Herrera, S. A., Pérez Rodríguez, M. A., \& Ramírez Godina, F. (2019). Seed physiological potential of Capsicum annuum var. glabriusculum genotypes and their answer to pre-germination treatments. Agronomy, 9, 1-12. doi: 10.3390/agronomy9060325

Almeida, A., Castel-Branco, M., \& Falcão, A. (2002). Linear regression for calibration lines revisited: weighting schemes for bioanalytical methods. Journal of Chromatography B, 774, 215-222. doi: 10.1016/s1570-0232(02)00244-1

Barkawi, L. S, Tam, Y. Y., Tillman, J. A., Normanly, J., \& Cohen, J. D. (2010). A highthroughput method for the quantitative analysis of auxins. Nature Protocols, 5, 16091618. doi: 10.1038/nprot.2010.118

Baskin, C. C., \& Baskin, J. M. (2014). Seeds: ecology, biogeography, and evolution of dormancy and germination. Second edition. Academic Press, San Diego, California, USA

Baskin, J. M., \& Baskin, C. C. (2004). A classification system for seed dormancy. Seed Science Research, 14, 1-16. https://doi.org/10.1079/SSR2003150

Bentsink, L., \& Koorneef, M. (2008). Seed dormancy and germination. The Arabidopsis book, 6, e0119. doi: $\underline{10.1199 / \text { tab.0119 }}$

Brady, S. M., Sarkar, S. F., Bonetta, D., \& McCourt, P. (2003). The abscisic acid insensitive 3 (ABI3) gene is modulated by farnesylation and is involved in auxin signaling and lateral root development in Arabidopsis. The Plant Journal, 34, 67-75. doi:10.1046/j.1365-313x.2003.01707.x

Cano-Vázquez, A., López-Peralta, A. C., Zavaleta-Mancera, H. A., Cruz-Huerta, N., Ramírez Ramírez, I., Gardea-Béjar, A., \& González-Hernández, V. A. (2015). Variación en grados de latencia en semillas entre colectas de chile piquín (Capsicum annuun var. glabriusculum). Botanical Sciences 93(1), 175-184. doi: 10.17129/botsci.138

Chiwocha, S. D., Cutler, A. J., Abrams, S. R, Ambrose, S. J., Yang, J., Ross, A. R., \& Kermode, A. R. (2005). The etr1-2 mutation in Arabidopsis thaliana affects the abscisic acid, auxin, cytokinin and gibberellin metabolic pathways during maintenance of seed dormancy, moist-chilling and germination. The Plant Journal, 42, 35-48. doi: 10.1111/j.1365-313X.2005.02359.x

De Souza, V., Fernandes dos Santos Dias, D. C., dos Santos Dias, L. A., \& Finger, F. L. (2011). Changes in seed quality during fruit maturation of sweet pepper. Sci. Agric, 68(5), 535539. http://dx.org/10.1590/S0103-90162011000500004

Demir, I., Mavi, K., \& Oztokat, C. (2004). Changes in germination and potential longevity of watermelon (Citrullus lanatus) seeds during development. New Zealand Journal of Crop and Horticultural Science, 139-145. https://doi.org/10.1080/01140671.2004.9514288 
Denancé, N., Sánchez, A., Goffner, D., \& Molina, A. (2013). Disease resistance or growth: the role of plant hormones in balancing immune responses and fitness costs. Front Plant Science, 4, 155. doi: 10.3389/fpls.2013.00155

Drew, P. J., Pammenter, N. W., \& Berjak, P. (2000). "Sub-imbibed" storage is not an option for extending longevity of recalcitrant seeds of the tropical species Trichilia dregeana Sond. Seed Science Research, 10(3), 355-363. https://doi.org/10.1017/S0960258500000398

Finch-Savage, W. E., \& Leubner-Metzger, G. (2006). Seed dormancy and the control of germination. New Phytologist, 171(3), 501-523. doi: 10.1111/j.14698137.2006.01787.x

Finkelstein, R., Reeves, W., Ariizumi, T., \& Steber, C. (2008). Molecular aspects of seed dormancy. Annual Review of Plant Biology, 59, 387-415. doi: 10.1146/annurev.arplant.59.032607.092740

Hentrich, M., Boettcher, C., Duchting, P., Cheng, Y., Zhao, Y., Berkowitz, O., Masle, J., Medina, J., \& Pollmann, S. (2013). The jasmonic acid signaling pathway is linked to auxin homeostasis through the modulation of YUCCA8 and YUCCA9 gene expression. The Plant Journal, 74, 626-637. doi: 10.1111/tpj.12152

Hernández-Verdugo, S., Porras, F., Pacheco-Olvera, A., López-España, R., Villarreal-Romero, M., Parra-Terraza, S., \& Osuna, T. (2012). Caracterización y variación ecogeográfica de poblaciones de chile (Capsicum annuum var. glabriusculum) silvestre del noroeste de México. Polibotánica, 33, 175-191.

Holdsworth, M. J., Bentsink, L., \& Soppe, W. J. (2008). Molecular networks regulating Arabidopsis seed maturation, after-ripening, dormancy and germination. New Phytologist, 179(1), 33-54. doi: 10.1111/j.1469-8137.2008.02437.x

Hulse-Kemp, A., Ashrafi, H., Plieske, J., Lemm, J., Stoffel, K., Hill, T., Luerssen, H., Pethiyagoda, C., Lawley, C., Ganal, M. W., \& Van Deynze, A. (2016). A Hap Map leads to a Capsicum annuum SNP infinium array: a new tool for pepper breeding. Horticulture Research 3, 16036. https://doi.org/10.1038/hortres.2016.36

Koprivova, A., \& Kopriva, S. (2016). Hormonal control of sulfate uptake and assimilation. Plant Molecular Biology, 91, 617-627. doi: 10.1007/s11103-016-0438-y

Leszek, J. (2003). Reguladores del crecimiento, desarrollo y resistencia en plantas. Mundi Prensa. México.

Leubner-Metzger, G. (2003). Functions and regulation of $\beta$-1,3-glucanases during seed germination, dormancy release and after-ripening. Seed Science Research, 13(1), 1734. https://doi.org/10.1079/SSR2002121

Linkies, A., \& Leubner-Metzger, G. (2012). Beyond gibberellins and abscisic acid: how ethylene and jasmonates control seed germination. Plant Cell Rep, 31(2), 253-270. doi: 10.1007/s00299-011-1180-1

Linkies, A., Graber, K., Knight, C., \& Leubner-Metzger, G. (2010). The evolution of seeds. New Phytologist, 186(4), 817-831. https://doi.org/10.1111/j.1469-8137.2010.03249.x

Ma, N., Xue. J., Li, Y., Liu, X., Dai, F., Jia, W., Luo, Y., \& Gao, J. (2008). RhPIP2;1, a rose aquaporin gene, is involved in ethylene-regulated petal expansion. Plant Physiology, 148, 894-907. https://doi.org/10.1104/pp.108.120154

Miransari, M., \& Smith, D. L. (2014). Plant hormones and seed germination. Environmental and Experimental Botany, 99,110-121.

Munné-Bosch, S., Onate, M., Oliveira, P. G., \& Garcia, Q. S. (2009). Changes in phytohormones and oxidative stress markers in buried seeds of Vellozia alata. Flora 206, 704-711. doi: 10.1016/j.flora.2010.11.012

Popko, J., Hänsch, R., Mendel, R. R., Polle, A., \& Telchmann, T. (2010). The role of abscisic acid and auxin in the response of poplar to abiotic stress. Plant Biol, 12(2), 242-58. doi: $10.1111 / \mathrm{j} .1438-8677.2009 .00305 . \mathrm{x}$

Preston, J., Tatematsu, K., Kanno, Y., Hobo, T., Kimura, M., Jikumaru, Y., Yano, R., Kamiya, Y., \& Nambara, E. (2009). Temporal expression patterns of hormone metabolism genes during imbibition of Arabidopsis thaliana seeds: a comparative study on 
Recibido:

18/marzo/2019

Aceptado:

2/julio/2020 dormant and non-dormant accessions. Plant Cell Physiology, 50, 1786-1800. doi: $10.1093 / \mathrm{pcp} / \mathrm{pcp} 121$

Quintero C., M. F., Guillen Castillo, O., Delgado Sánchez, P., Marín Sánchez, J., Guzman, A. I., Sánchez, A., \& Miguel Guzman, J. (2018). Relieving dormancy and improving germination of Piquin chili pepper (Capsicum annuum var. glabriusculum) by priming techniques. Soil \& Crop Sciences, 4, 1-13. https: //doi.org/10.1080/23311932.2018.1550275

Suttle, J., \& Banowetz, G. M. (2000). Changes in cis-zeatin and cis-zeatin riboside levels and biological activity during potato tuber dormancy. Physiologia Plantarum, 109, 68-74. https://doi.org/10.1034/j.1399-3054.2000.100110.x

Tarkowski, P., Ge, L., Yong, H. J., \& Ngin, S. (2009). Analytical methods for cytokinins. Trends in Analytical Chemistry, 28(3), 323-335. doi: 10.1016/j.trac.2008.11.010

Tommasi, F., Paciolla, M., de Pinto, M. C., \& de Gara, L. (2006). Effects of storage temperature on viability, germination and antioxidant metabolism in Ginkgo biloba L. seeds. Plant Physiology Biochemistry, 44, 359-368. doi: 10.1016/j.plaphy.2006.06.014

Wang, Y., \& Irving, H. R. (2011). Developing a model of plant hormone interactions. Plant Signaling \& Behavior, 6, 494-500. doi: 10.4161/psb.6.4.14558

Yamaguchi, S. (2008). Gibberellin metabolism and its regulation. Annual Review of Plant Biology, 59, 225-251. https://doi.org/10.1146/annurev.arplant.59.032607.092804

Yamamoto, S., \& Nawata, E. (2005). Capsicum frutescens L. in southeast and east Asia, and its dispersal routes into Japan. Economic Botany, 59, 18-28. https://doi.org/10.1663/00130001(2005)059[0018:CFLISA]2.0.CO;2

Yamauchi, Y., Ogawa, M., Kuwahara, A., Hanada, A., Kamiya, Y., \& Yamaguchi, S. (2004). Activation of gibberellin biosynthesis and response pathways by low temperature during imbibition of Arabidopsis thaliana seeds. Plant Cell, 16, 367-378. https://doi.org/10.1105/tpc.018143 